\title{
PENGEMBANGAN E-MODUL BERBASIS INKUIRI UNTUK PEMBELAJARAN GEOMETRI PADA PROGRAM STUDI PGSD
}

\author{
I Ketut Suastika $^{1}$, Dyah Triwahyuningtyas ${ }^{2}$ \\ ${ }^{1,2}$ Pendidikan Guru Sekolah Dasar, Universitas Kanjuruhan Malang, Indonesia \\ ${ }^{1}$ suastika@unikama.ac.id \\ 2dyahtriwahyu@unikama.ac.id
}

\begin{abstract}
Abstrak: Tujuan penelitian ini adalah untuk mengembangkan e-modul berbasis inkuiri untuk matakuliah Pembelajaran Geometri pada Program Studi Pendidikan Guru Sekolah Dasar (PGSD). Tahapan pengembangan yang digunakan dalam penelitian ini adalah tahapan pengembangan Plomp meliputi: investigasi awal, prototipe, dan asesmen. Pada tulisan ini, peneliti hanya fokus pada pemaparan hasil dari investigasi awal. Investigasi awal dilakukan pada prodi PGSD di kampus yang berafiliasi PGRI di Jawa Timur. Hasil yang diperoleh pada investigasi awal: (1) materi yang disajikan pada pembelajaran geometri meliputi materi bangun datar dan materi bangun ruang, (2) pembelajaran yang dilaksanakan didominasi oleh dosen, (3) ada bahan ajar yang digunakan sebagai pegangan, namun masih belum menggunakan e-modul, (4) bahan ajar yang digunakan masih belum memberikan porsi yang cukup untuk mahasiswa menemukan konsep.
\end{abstract}

Katakunci: Pengembangan; E-Modul; Inkuiri.

\begin{abstract}
The purpose of this study is to develop an inquiry-based e-module for the Geometry Learning course in the Elementary School Teacher Education Study Program (PGSD). The stages of development used in this research are the stages of Plomp development including: preliminary research, prototyping phase, and assessment phase. In this paper, researchers only focus on the presentation of the results of the preliminary research. Preliminary research were carried out on PGSD study programs at PGRI affiliated campuses in East Java. The results obtained at the preliminary research: (1) the subject matter presented in geometry learning includes plane and solid, (2) learning is dominated by lecturers, (3) there are teaching materials that are used as a handle, but still not using e-modules, (4) teaching materials use still do not provide sufficient portions for students to find concepts.
\end{abstract}

Keywords: Development; E-Module; Inquiry.

\section{Pendahuluan}

Program studi Pendidikan Guru Sekolah Dasar (PGSD) memiliki lima bidang ilmu yang wajib ditempuh oleh peserta didiknya, salah satunya adalah bidang matematika. Matematika bukanlah ilmu menghafal (Suryawati, Osman, \& Meerah, 2010). Matematika mengajarkan untuk berfikir logis, analitis, sistematis, kritis, dan kreatif (Hadar, 2017). Pada bidang matematika, matakuliah yang wajib tempuh tersebut salah satunya adalah matakuliah Pembelajaran Geometri. Matakuliah ini sangat penting bagi mahasiswa yang nantinya akan terjun menjadi guru di Sekolah Dasar (SD) mengingat contentnya yang memuat konsep dan bagaimana mengajarkan materi geometri di SD. Namun demikian, (González, 2013) mengemukakan bahwa penyampaian konsep rumus luas dan volume pada pembelajaran geometri masih bersifat hafalan. Penguasaan konsep yang diperoleh dengan cara hafalan tentu tidak akan bertahan lama di memori mahasiswa. Untuk mengatasi hal itu maka diperlukan suatu langkahlangkah penelusuran konsep yang 
membimbing mahasiswa untuk menemukan sendiri konsep untuk luas daerah bangun datar dan juga volume bangun ruang.

Pendekatan inkuiri dirancang untuk mengajak mahasiswa secara langsung ke dalam proses ilmiah dalam merangsang mahasiswa untuk berfikir, menganalisa suatu permasalahan sehingga menemukan pemecahannya (Alameddine \& Ahwal, 2016). Pendekatan ini bertolak dari pandangan bahwa mahasiswa sebagai subjek dan objek dalam belajar mempunyai kemampuan dasar untuk berkembang secara optimal sesuai kemampuan yang dimilikinya (Serafín and Havelka, 2015). Sementara itu, buku matematika yang beredar di pasaran, secara umum memberikan konsep dalam bentuk jadi kepada mahasiswa. Tidak memberikan kesempatan mahasiswa untuk dapat menelusuri dari mana suatu konsep itu diperoleh. Hal ini yang menyebabkan kebanyakan mahasiswa hanya menghafal dalam belajar matematika. Dampak dari penggunaan bahan ajar seperti itu, mahasiswa kesulitan memahami materi matematika serta kemampuan individu mahasiswa juga kurang berkembang secara maksimal.

Menurut Ruseffendi seperti dikutip oleh Wulandari (2015), selama ini matematika yang dipelajari di sekolah diperoleh melalui pemberitahuan (dengan cara ceramah/ekspositori), bacaan, meniru, melihat, mengamati dan sebagainya, bukan diperoleh melalui penemuan. Hal ini menyebabkan terjadinya berbagai kesalahan dalam memahami konsep matematika. Berdasarkan pendapat ini, maka konsep matematika tidak boleh diberikan dalam bentuk jadi. Artinya konsep-konsep yang ada dalam matematika tidak boleh dipindahkan langsung dari dosen kepada mahasiswa sebab di dalamnya mengandung proses abstraksi, dimana mahasiswa harus dilibatkan dalam proses penemuannya. Hal ini berarti, dalam kegiatan belajar masih diperlukan bahan ajar lain seperti bahan ajar dengan pendekatan inkuiri yang relevan dengan tuntutan kurikulum 2013 yang menekankan pada ketrampilan proses.

Saat ini adalah era digital. Perkembangan teknologi informasi pada era digital ini memberikan dampak yang luar biasa dalam beberapa aspek kehidupan, salah satunya pada aspek pendidikan. Banyak sumber belajar yang dapat diakses dengan mudah hanya menggunakan smartphone. Oleh karena itu, tidak salah kiranya kementrian ristekdikti mendorong supaya perguruan tinggi menerapkan pembelajaran secara online.

Saat ini banyak perguruan tinggi ternama di dunia yang menyelenggarakan perkuliahan jarak jauh dengan perkuliahan secara online. Dengan sistem pembelajaran secara online, mahasiswa dari manapun dapat mengikuti perkuliahan tersebut (Chena et al., 2015). Ada keunggulan kalau pembelajaran dilaksanakan secara online, setiap mahasiswa dapat belajar dimana saja dan kapan saja, asalkan terkoneksi jaringan internet (Dore et al., 2018). Komunikasi online juga dapat dilakukan berulang, artinya, kalau sekali melihat belum paham materinya, maka dapat dilihat ulang lagi. Dengan komunikasi secara online seperti itu tentu akan memupuk kemandirian mereka.

Program studi PGSD sebagai lembaga yang dipercaya untuk mencetak calon guru yang dipersiapkan menjadi pendidik di sekolah dasar, secara fisik dan psikis perlu dipersiapkan untuk siap melaksanakan pembelajaran di era digital ini. Program studi PGSD, mau tidak mau juga harus melaksanakan pembelajaran secara online. Untuk melaksanakan pembelajaran secara online tentu juga harus dipersiapkan bahan ajar yang 
berupa bahan ajar elektronik yang berkualitas.

\section{Metode Penelitian}

Fokus penelitian ini akan mengembangkan suatu produk bahan ajar matakuliah pembelajaran geometri. Tahapan penelitian yang dilakukan peneliti dalam pengembangan ini, merujuk pada tahapan yang dikemukakan Plomp (2013). Ada 3 (tiga) tahapan (fase) yang dikemukakan Plomp, yaitu:

1. Fase Investigasi Awal (Preliminary Research)

Investigasi yang dilakukan peneliti pada tahapan ini antara lain: (1) analisis materi yang disajikan pada pembelajaran geometri, mengkaji sumber-sumber belajar seperti buku teks, buku penunjang lainnya untuk pembelajaran geometri yang sedang berjalan, dan (3) analisis pengalaman siswa dalam belajar geometri.

2. Fase Prototipe (Prototyping Phases) Berdasarkan hasil investigasi awal, disusun rancangan penyelesaian masalah. Rancangan yang dibuat terdiri dari; (1) rancangan e-modul pembelajaran geometri dengan pendekatan inkuiri, (2) rancangan Rencana Pelaksanaan Pembelajaran (RPP) yang sesuai dengan langkah pembelajaran inkuiri, dan rancangan instrumen penelitian, yang terdiri dari: Lembar Validasi emodul, Lembar Validasi RPP, Lembar Observasi Keterlaksanaan pembelajaran, Lembar Observasi Mahasiswa, Angket Respon Mahasiswa, serta Tes Penguasaan Bahan Ajar.

3. Fase Asesmen (Assessment Phases) Dua aktivitas dalam fase ini adalah validasi e-modul dan uji coba emodul pada situasi nyata di kelas perkuliahan.

\section{Hasil dan Pembahasan}

Penelitian ini baru pada tahap investigasi awal. Pada investigasi awal ini, peneliti melakukan observasi ke kampus-kampus berafiliasi PGRI yang memiliki prodi PGSD Di Jawa Timur. Observasi dilakukan melalui wawancara dengan kaprodi PGSD, dosen pengampu matakuliah matematika di PGSD, dan juga mahasiswa PGSD. Berikut beberapa poin dari hasil yang diperoleh pada investigasi awal ini:

1. Sajian materi untuk geometri semuanya sama, yaitu materi bangun datar dan bangun ruang. Hal tersebut bisa dimaklumi karena memang materi geometri di sekolah dasar juga membicarakan bangun datar dan bangun ruang. Untuk materi bangun datar meliputi: sifat-sifat bangun datar, keliling dan luas bangun datar. Untuk materi bangun ruang meliputi jaring-jaring bangun ruang, volume, dan luas permukaan bangun ruang.

2. Ada buku ajar yang digunakan dosen dalam menyampaikan materi geometri tersebut, hanya saja masih belum berupa e-modul.

3. Sajian materi pada buku ajar yang digunakan dosen sebagai buku pegangan belum memberikan kesempatan kepada mahasiswa untuk menemukan konsep, baik itu konsep luas bangun datar maupun konsep volume bangun ruang.

4. Hasil wawancara dengan beberapa mahasiswa, kebanyakan dari mereka merasa kesulitan dalam memperoleh rumus luas daerah bangun datar maupun volume bangun ruang.

5. Ketakutan para dosen akan kemampuan penguasaan mahasiswa lemah terkait konsep-konsep yang ada pada pembelajaran geometri menyebabkan para dosen dengan ekstra keras menjelaskan supaya konsepnya bisa dipahami oleh mahasiswanya tersebut. 
Berdasarkan hasil investigasi awal tersebut, peneliti mengembangkan emodul berbasis inkuiri.

Perlu disadari bahwa kemampuan mahasiswa dalam menerima dan merespon materi perkuliahan berbeda. Perbedaan tersebut mengakibatkan ada mahasiswa yang kurang memperhatikan atau sibuk dengan aktivitas lain ketika dosen menyampaikan materi perkuliahan di kelas. Ini mengindikasikan tidak bisa semua mahasiswa terlayani kebutuhannya secara individu. Strategi yang dapat digunakan untuk mewadahi kebutuhan secara individu adalah pembelajaran dengan menggunakan modul. Modul berfungsi sebagai sarana belajar yang bersifat mandiri, sehingga mahasiswa dapat belajar sesuai dengan kecepatan masing-masing. Parmin (2012) mengatakan, the module is one of the important components in learning as it can help students obtain important information about the learning materials. Wahyuningtyas dan Suastika (2016) mengatakan, penerapan modul dapat mengkondisikan kegiatan pembelajaran lebih terencana dengan baik, mandiri, tuntas dan dengan hasil (output) yang jelas. Hal yang hampir senada juga disampaikan oleh Rufii (2015), One of media that can make students able to work independently to analy zerotational motion is the module.

Seiring dengan perkembangan teknologi dan komunikasi yang semakin pesat, tentu tidak bisa dihindari layanan belajar mahasiswa juga perlu dikembangkan dengan adanya bahan ajar elektronik (Letchumanan \& Ahmad, 2010). Bahan ajar elektronik dapat berupa e-modul atau e-book. E-Module merupakan sebuah bentuk penyajian bahan belajar atau sarana pembelajaran yang berisi materi, metode, batasanbatasan, dan cara mengevaluasi yang dirancang secara sistematis dan menarik untuk mencapai kompetensi sesuai dengan tingkat kompleksitasnya secara elektronik (Letchumanan, M. and Ahmad, R. 2010) Hasil penelitian Imansari (2017) memperlihatkan, bahwa mahasiswa cenderung lebih senang menggunakan sumber belajar elektronik daripada sumber belajar cetak, mengingat modul elektronik dapat menampilkan teks, gambar, animasi, dan juga video interaktif. Sementara itu (Letchumanan \& Ahmad, 2010) mengatakan bahwa sebagian besar mahasiswa lebih tertarik menggunakan e-book untuk membantu menyelesaikan tugas. Oleh karena itu, untuk melatih kemandirian mahasiswa maka perlu dikembangkan e-book dalam bentuk e-modul pada mata kuliah pembelajaran geometri.

Inkuiri merupakan metode pembelajaran yang berupaya menanamkan dasar-dasar berfikir ilmiah pada diri mahasiswa, sehingga dalam proses pembelajarannya mahasiswa lebih banyak belajar sendiri, mengembangkan kreativitas dalam memecahkan masalah. Mahasiswa benar-benar ditempatkan sebagai subjek belajar (Siagian, dan Nurfitriyani, 2012). Oleh karena itu, dalam perencanaan proses pembelajaran, dosen bukanlah mempersiapkan sejumlah materi yang harus dihafal melainkan merancang pembelajaran yang memungkinkan mahasiswa menemukan sendiri materi yang harus dipahami melalui proses berfikir secara sistematis (Siagian dan Nurfitriyani, 2012). Belajar melalui proses mencari dan menemukan (inkuiri) ini tentu mahasiswa akan menggunakan segala potensinya untuk menemukan konsep-konsep sehingga menyebabkan pemahaman terhadap konsep tersebut bertahan lama. Pengetahuan yang diperoleh dengan belajar penemuan menunjukkan pengetahuan itu bertahan lama atau lama diingat atau lebih mudah diingat bila dibandingkan dengan pengetahuan yang dipelajari dengan cara-cara lain (Decker- 
lange, 2018). Secara menyeluruh belajar melalui penemuan meningkatkan penalaran siswa dan kemampuan untuk berfikir secara bebas (Pedaste et al., 2015)

\section{Kesimpulan}

Dalam era digital, E-modul berbasis inkuiri menjadi solusi untuk pembelajaran geometri pada Program Studi PGSD.

\section{Daftar Rujukan}

Alameddine, M. M. and Ahwal, H. W. 2016. Inquiry Based Teaching in Literature Classrooms. Procedia Soc. Behav. Sci., vol. 232, no. April, pp. 332-337.

Chena, T.. Weib, H.. Chengc, Y.. Leud, J.. Shiha, W.and Hsua, N. 2015. Integrating an e-book software with vector graphic technology on cloud platform. Procedia - Soc. Behav. Sci., vol. 176, pp. 10121019.

Decker-lange, C. . 2018. The International Journal of Problemand inquiry-based learning in alternative contexts : Using museums in management education. Int. J. Manag. Educ., vol. 16, no. 3, pp. 446-459

Dore, R. A. et al.. 2018. Early Childhood Research Quarterly The parent advantage in fostering children's e-book comprehension. Early Child. Res. Q., vol. 44, pp. 24-33

González, G. 2013. A geometry teacher's use of a metaphor in relation to a prototypical image to help students remember a set of theorems. J. Math. Behav., vol. 32, no. 3, pp. 397-414.

Hadar, L. L. 2017. Opportunities to learn: Mathematics textbooks and students' Achievements. Stud. Educ. Eval.. vol. 55, no. August, pp. 153-166.
Imansari,N. Dan Sunaryatiningsih, I. 2017. Pengaruh Penggunaan EModul Interaktif Terahdap Hasil Belajar Mahasiswa Pada Materi Kesehatan dan Keselamatan Kerja. Jurnal Untirta /index.php/VOLT, vol 2, No.1, p 11-16

Letchumanan, M. and Ahmad, R.. 2010. Utilization of e-book among University Mathematics Students. Procedia - Soc. Behav. Sci., vol. 8, no. 5 , pp. $580-587$

Parmin \& Peniati. E. 2012. Development of Course Module Learning Strategy of Teaching Science Based on Science Result of Science. Indonesian Science. Education Journal, 1(1), 23391286.

Pedaste, M., Mäeots, M., Siiman, L. A., De Jong, T., Zacharia, Z. C., and Tsourlidaki, E. 2015. Phases of inquiry-based learning: Definitions and the inquiry cycle. Educ. Res. Rev., vol. 14, pp. 4761.

Plomp, T.. 20013. Educational Design Research. Netherlands Institute for Curriculum Development (SLO). Enschede, the Netherlands.

Rufii. 2015. Developing Module on Constructivist Learning Strategies to Promote Students' Independent and Performance. Internasional Journal of Education, 7(1), 19485476.

Serafín, C. and Havelka, M. 2015. Inquiry-Based Instruction in The Context of Constructivism. Procedia - Soc. Behav. Sci., vol. 186, pp. 592-599.

Siagian, R.E.F. dan Nurfitriyani, M. 2012. Metode Pembelajaran Inquiry dan Pengaruhnya Terhadap Hasil Belajar Matematika Ditinjau dari 
Kreativitas Belajar. Jurnal Formatif 2(1): 35-44

Suryawati, K. Osman, and Meerah, T. S. M. 2010 . The effectiveness of RANGKA contextual teaching and learning on student's problem solving skills and scientific attitude. Procedia - Soc. Behav. Sci.. vol. 9, pp. 1717-1721.

Wahyuningtyas, D. T. and Suastika, I. K. 2016. Developing Of Numbers Learning Module For P Rimary
School Students By Contextual Teaching And Learning Approach, Jurnal Pendidik. Dasar Indonesia., vol. 1, September, pp. 33-36.

Wulandari, D.P. 2015. Meningkatkan Pemahaman Konsep Matematika Siswa SD Melalui Pembelajaran dengan Pendekatan Problem Posing. Jurnal Pendidikan Dasar Edu Humaniora, 7(2) 